Volume 3 No 1 (2020) 194-218 P-ISSN 2620-2956

DOI 10.47467/elmal.v3i1.298

\title{
Kajian Motif Pemilihan Skema Pembiayaan LKMA PUAP di Jawa Tengah
}

\author{
Dedi Junaedi \\ Dosen Ekonomi dan Keuangan Syariah, Program Studi Perbankan Syariah, \\ Fakultas Ekonomi dan Bisnis Islam, Institut Agama Islam Syahid Bogor
}

\begin{abstract}
The objective of this research is to explore the motif election financing scheme Rural Agribusiness Development (PUAP), knowing what factors affect the performance PUAP, and test whether performance sharia PUAP different from conventional PUAP in Central Java in 2008-2011. The study was conducted in the District of Banjarnegara, Banyumas, Jepara, Kendal and Kendal during the period from July to December 2012 Using qualitative and quantitative methods with a dummy variable multiple regression approach, the manager LKMA PUAP 185 respondents of this study with purposive sampling approach. From about 2267 LKMA PUAP in Central Java, the majority (87.25\%) chose to operate with conventional financing scheme and only 289 (12.75\%) which apply sharia scheme or the principle of profit sharing (profit sharing). Research shows PUAP sharia been selected for the motive of religious considerations (40.6\%), while the conventional PUAP been LKMA practical reasons (35.3\%) and the economy (30.2\%). In the perception of respondents, LKMA PUAP sharia is considered more appropriate to the creed, manifestations of worship, fields expectation of reward, blessing and benefit. PUAP LKMA conventionally considered more practical, safe, and familiar with the daily habits of members. Statistical analysis showed motif election financing scheme LKMA significantly affected by the financing scheme (Sharia), education level (Educate), and regional differences (Kab). Motif scheme selection is also different between the respondent and the respondent voters LKMA sharia conventional LKMA voters.
\end{abstract}

Keywords:Agribusiness, direct aid societies, microfinance, motif, PUAP, Sharia.

\section{ABSTRAK}

Penelitian ini bertujuan untuk mengeksplorasi motif pemilihan skema pembiayaan Pengembangan Usaha Agribisnis Perdesaan (PUAP), mengetahui faktor apa saja yang memengaruhi kinerja PUAP, serta menguji apakah kinerja PUAP syariah berbeda dengan PUAP konvensional di Jawa Tengah tahun 20082011. Penelitian dilakukan di Kabupaten Banjarnegara, Banyumas, Jepara, Kendal, dan Kendal selama 


\author{
Volume 3 No 1 (2020) 194-218 P-ISSN 2620-2956 \\ DOI 10.47467/elmal.v3i1.298
}

periode Juli-Desember 2012 Menggunakan metode kualitatif dan kuantitatif dengan pendekatan multiple regression dummy variable, 185 manajer LKMA PUAP menjadi responden penelitian ini dengan pendekatan purposive sampling. Dari sekitar 2267 LKMA PUAP di Jawa Tengah, sebagian besar $(87,25 \%)$ memilih beroperasi dengan skema pembiayaan konvensional dan hanya 289 (12,75\%) yang menerapkan skema syariah atau prinsip bagi hasil (profit sharing). Hasil riset menunjukkan PUAP syariah dipilih karena motif pertimbangan agama $(40,6 \%)$, sementara LKMA PUAP konvensional dipilih alasan praktis (35,3\%) dan ekonomi (30,2\%). Dalam persepsi responden, LKMA PUAP syariah dinilai lebih sesuai tuntutan akidah, bentuk manifestasi ibadah, ladang harapan mendapat pahala, keberkahan dan kemaslahatan. LKMA PUAP konvensional dinilai lebih praktis, aman, dan akrab dengan kebiasaan keseharian anggota. Hasil uji statistik menunjukkan motif pemilihan skema pembiayaan LKMA dipengaruhi secara nyata oleh skema pembiayaan (Sharia), tingkat pendidikan (Didik), dan perbedaan kawasan (Kab). Motif pemilihan skema juga berbeda antara responden pemilih LKMA syariah dan responden pemilih LKMA konvensional.

Kata Kunci: Agribisnis, bantuan langsung masyarakat, lembaga keuangan mikro, motif, PUAP, syariah.

\title{
PENDAHULUAN
}

Perekonomian Indonesia tumbuh positif dari tahun ke tahun. Namun, jumlah penduduk miskin masih relatif tinggi. BPS mencatat, tahun 2012 jumlah penduduk miskin ada 29,13 juta jiwa (BPS, 2012). Dari jumlah tersebut, sekitar 18,48 juta jiwa atau $63,4 \%$ hidup sebagai petani di perdesaan. Mengingat mayoritas penduduk miskin adalah petani, maka pembangunan ekonomi nasional berbasis pertanian dan perdesaan memiliki peran strategis.

Di antara permasalahan mendasar yang dihadapi petani adalah kurangnya akses petani kepada sumber permodalan, pasar dan teknologi, serta organisasi tani yang masih lemah (Apriyantono, 2009). Untuk mengatasi permasalahan ini,Departemen Pertanian (kini Kementerian Pertanian) menggulirkan program Pengembangan Usaha Agribisnis Pedesaan (PUAP) sebagai satu solusi untuk membantu pengembangan usaha tani yang umumnya profitable tetapi belum bankable. Terinspirasi keberhasilan Yunus mengembangkan Grameen Bank di Bangladesh, PUAP merupakan program rintisan untuk menumbuhkembangkan 


\section{Volume 3 No 1 (2020) 194-218 P-ISSN 2620-2956 \\ DOI 10.47467/elmal.v3i1.298}

Lembaga Keuangan Mikro Agribisnis (LKMA) dengan prinsip bagi hasil atau skema profit loss sharing (syariah).

PUAP merupakan bentuk fasilitasi bantuan modal usaha bagi petani anggota, baik petani pemilik, petani penggarap, buruh tani maupun rumah tangga tani yang dikoordinasikan oleh gabungan kelompok tani (Gapoktan). Dalam Petunjuk teknisnya disebutkan bahwa dana bantuan langsung masyarakat (BLM) Rp 100 juta per desa/gapoktan menjadi modal awal bagi unit usaha simpan pinjam milik Gapoktan. Tumbuh dan berkembangnya LKMA PUAP menjadi indikator penting keberhasilan program PUAP secara keseluruhan.

Selama periode 2008-2011, PUAP telah dilaksanakan di 38.123 desa/gapoktan sebagai pusat pertumbuhan usaha agribisnis di pedesaan (Hendriawan, 2011). Dalam perjalanannya, Gapoktan PUAP ternyata memiliki kinerja opersional yang bervariasi. Ada yang berkembang pesat dan tumbuh menjadi LKMA, ada yang masih berusaha tumbuh menjadi LKMA, ada yang jalan di tempat masih sebagai Gapoktan pelaksana simpan-pinjam anggota.

Menurut hasil evaluasi Tim PUAP Pusat, kini sudah terbentuk sekitar 3.000 LKMA yang tersebar di seluruh pelosok Indonesia (Hendriawan, 2011). Sebagian besar LKMA itu beroperasi seperti koperasi, menerapkan skema bunga pinjaman dan iuran anggota. Sementara sebagian kecil lainnya beroperasi dengan skema bagi hasil (profit loss sharing) atau sistem keuangan syariah.(Sudaryanto, 2009).

Permasalahan yang menarik untuk dicermati ialah bahwa dari 4665 Gapoktan PUAP selama periode 2008-2011, hampir separuhnya (2267) sudah berbentuk LKMA. Jumlah ini setara dengan $75,6 \%$ populasi LKMA PUAP secara nasional. Dari jumlah itu, sekitar 287 atau 12,66\% LKMA di Jateng beroperasi dengan skema pembiayaan syariah. Sisanya, 82,34\% beroperasi seperti LKMA konvensional, memakai skema bunga pinjaman. Berdasarkan data dan fakta tersebut, maka, timbul pertanyaan penelitian sebagai berikut:

1. Apa saja yang menjadi motif Gapoktan di Jawa Tengah dalam memilih LKMA dengan skema syariah atau konvensional

2. Faktor apa saja yang memengaruhi pemilihan skema syariah atau konvensional LKMA di Jawa Tengah?

Penelitian ini ditujukan untuk: 


\section{Volume 3 No 1 (2020) 194-218 P-ISSN 2620-2956 \\ DOI 10.47467/elmal.v3i1.298}

1. Mengetahui motif pemilihan LKMA PUAP dengan skema syariah atau LKMA PUAP dengan skema konvesional di Jawa Tengah.

2. Mengetahui dan mengeksplorasi faktor-faktor yang memengaruhi pemilihan skema pembiayaan LKMA PUAP dengan skema syariah dan konvensional di Jawa Tengah.

\section{KERANGKA PEMIKIRAN}

LKMA adalah lembaga keuangan mikro yang tumbuh dari Gapoktan PUAP dengan fungsi utama mengelola aset dasar dari dana PUAP dan dana swadaya angggota (Kementerian Pertanian, 2010). Dana yang dikelola LKMA dimanfaatkan secara maksimal untuk membiayai usaha agribisnis anggota dengan skema pembiayaan konvensional (sistem bunga pinjaman) dan skema syraiah (profit loss sharing) atau sistem bagi hasil. LKMA pada dasarnya merupakan bagian dari lembaga keuangan mikro yang tugas utamanya memberi fasilitas pinjaman atau pembiayaan usaha agribisnis untuk para anggota kelompok tani.

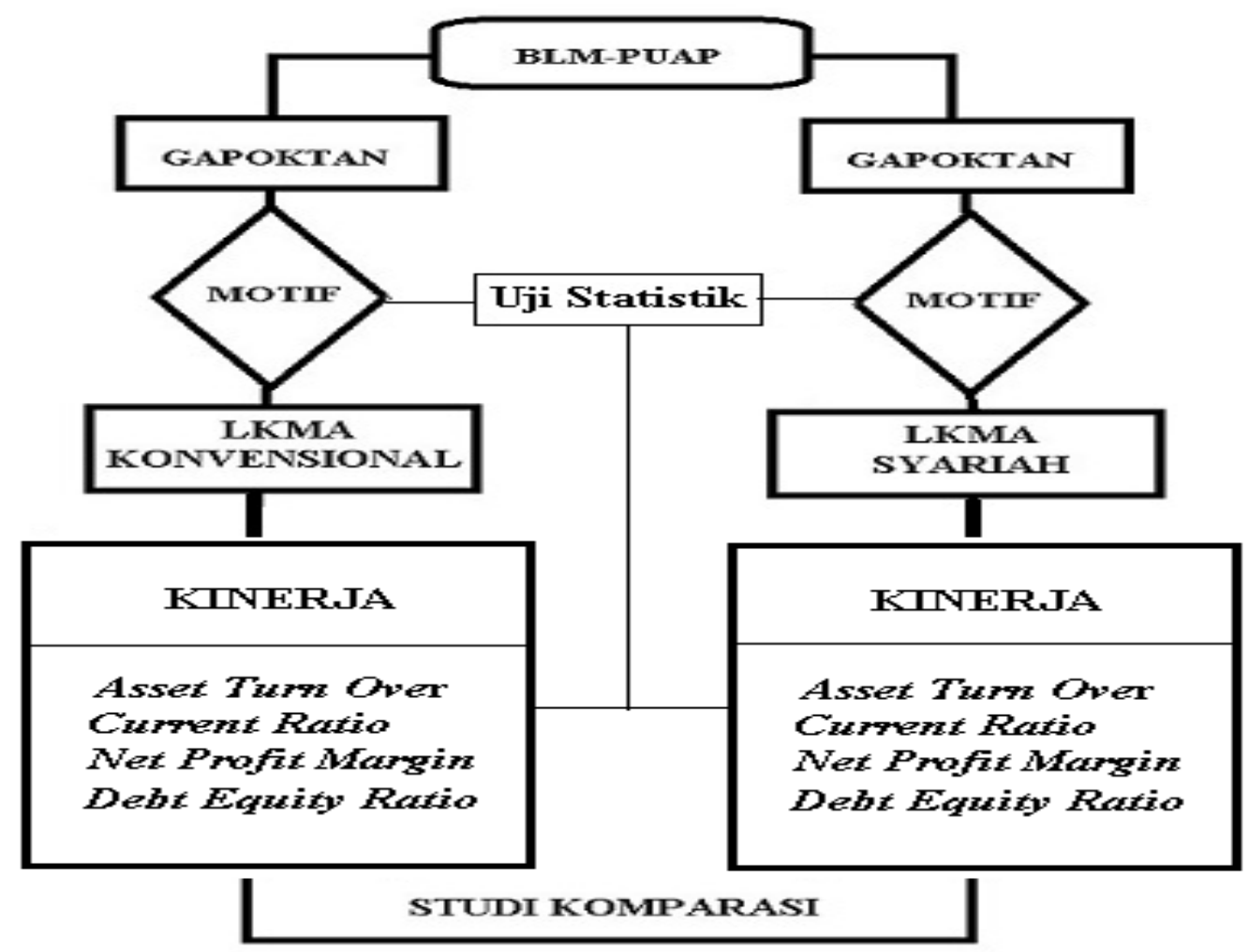

Gambar 1 Skema Komparasi Kinerja PUAP Syariah dan Konvensional 


\section{Volume 3 No 1 (2020) 194-218 P-ISSN 2620-2956 \\ DOI 10.47467/elmal.v3i1.298}

Pengukuran kinerja aspek managemen pengelolaan LKMA pada Gapoktan merupakan suatu kegiatan untuk mengetahui pola pengelolaan keuangan (manajemen keuangan) di tingkat Gapoktan PUAP oleh pengurus (Hendriawan, 2012). Bagaimana mengukur kinerja LKM? Hussein (2010) menawarkan tiga indikator penting. Pertama, kinerja ROA atau Return on Asset; kedua, nilai Tobin Q yang dihitung dari equitas dibagi laba bersih; dan ketiga, likuiditas yang didekati dengan menghitung rasio aset atas liabilitasnya atau Rasio Lancar. Kinerja LKM juga dapat dilihat dari besarnya tingkat kepercayaan yang ditunjukkan oleh rasio tabungan datau depositnya. Besarnya deposit menunjukkan tingginya kepercayaan nasabah atau anggota terhadap LKM-nya. Zohra Bi dan Pandey (2011) menawarkan neraca laba-rugi, kredit macet, dan rasio kecukupan modal sebagai indikator penting menilai kinerja LKM di India.

Dalam menilai kinerja sebuah lembaga usaha, Keown (2011) menawarkan empat katagori kinerja, yaitu: Likuiditas (Rasio Lancar, Rasio Cepat), Profitabilitas (diwakili Net Profit Margin (NPM), Gross Profit Margin (GPM), Operating Profit Margin (OPM), Solvabilitas (diwakili Debt Asset Ratio (DAR), Debd Equity Ratio (DER), Capital Adequacy Ratio (CAR) dan Pengembalian Ekuitas (diwakili Return on Equity (ROE), Return on Asset (ROA)). Subramanyam (2010) dan Margaretha (2011) menambahkan aspek Aktivitas seperti perputaran penjualan per aset (Asset Turn Over (ATO)) dan rasio biaya per pendapatan Expense Ratio (X/R).

LKM syariah, menurut Rahman (2007), cukup efektif menciptakan lapangan kerja dan menurunkan kemiskinan di sejumlah negara berkembang. Mudarabah, musharakah, murabahah, ijarah termasuk skema pembiayaan yang umum dilayani LKM Syariah di Malaysia.

\section{STUDI TERDAHULU}

Penelitian Khandker terhadap Grameen Bank di Bangladesh menyimpulkan bahwa terdapat empat faktor yang saling berkaitan sehubungan dengan kelangsungan hidup dan kinerja lembaga kredit mikro yaitu faktor keuangan, institusi, nasabah dan kondisi ekonomi (Khandker et al, 1995). Secara spesifik berdasarkan hasil penelitian terhadap dua jenis LKM di Indonesia, Kaluge menyimpulkan bahwa kesinambungan hidup lembaga kredit mikro tergantung pada tingkat keuntungan yang dipengaruhi oleh faktor besarnya penerimaan, biaya operasional, tingkat angsuran, besarnya bunga pinjaman dan tingkat efisiensi usaha. (Kaluge,2008).

Sudaryanto dan Sunarja (2009) mendapatkan fakta bahwa penggunaan dana BLM PUAP dan perkembangan Gapoktan beragam, tergantung dari kondisi awal pembentukan Gapoktan. 


\section{Volume 3 No 1 (2020) 194-218 P-ISSN 2620-2956 \\ DOI 10.47467/elmal.v3i1.298}

Kinerja Gapoktan yang baik dan maju umumnya adalah Gapoktan yang berasal dari kelompok tani bekas binan program sebelumnya seperti Primatani, P4K, PIDRA, Desa Mandiri Pangan dan kelompok tani BLM lainnya. Pada Gapoktan bentukan baru, pengunaan dana BLM PUAP terkesan hanya bagi-bagi bantuan akibat rendahnya SDM pengurus Gapoktan.

Rivai (2010) melakukan riset evaluasi dan penyusunan desa calon lokasi PUAP. Mereka menumukan fakta bahwa seluruh Gapoktan mampu mengembangkan kegiatan usaha simpan pinjam. Namun, perguliran dana bantuan menunjukan keragaman, tergantung pada dinamika manajemen dan kemampuan Gapoktan sebagai lembaga usaha agroibisnis bertujuan komersial. Kamira, Noer dan Tan (2011) dari Universitas Andalas secara khusus melakukan riset evaluasi pelaksanaan Program Pengembangan Usaha Agribisnis Pedesaan (PUAP) di Kota Padang, Sumatra Barat. Hasilnya, pelaksanaan program PUAP di Kota Padang belum sepenuhnya dilaksanakan sesuai dengan ketentuan.

Kinerja lembaga pembiayaan pedesaan bisa dilihat dari dua sisi yaitu sisi pencapaian sasaran (outreach) dan segi kelangsungan hidup lembaga (sustainability). Dari hasil penelitian di Jawa Timur, Zain (2001) mengemukakan bahwa terdapat 4 (empat) indikator yang bisa digunakan untuk menilai kinerja lembaga kredit mikro yaitu: stabilitas dan kinerja usaha nasabah, pendapatan dan asset anggota binaan, derajat ketergantungan nasabah pada rentenir, dan stabilitas kelangsungan hidup lembaga. Dia mengemukakan bahwa lembaga kredit mikro yang mempunyai kinerja tinggi adalah lembaga yang jumlah nasabahnya semakin banyak dengan nilai pinjaman yang semakin besar, pelayanannya semakin mudah dijangkau, nilai asetnya semakin besar, nilai tabungan anggota binaan semakin tinggi, dan tingkat pengembalian pinjaman yang tinggi.

Penelitian Khandker dan Farugee (2001) terhadap Grameen Bank di Bangladesh mengemukakan bahwa terdapat 4 (empat) konsep yang saling berkaitan sehubungan dengan kelangsungan hidup dan kinerja lembaga yaitu : viabilitas keuangan, viabilitas ekonomi, viabilitas institusi, dan viabilitas nasabah. Hasil penelitian Bank Dunia terhadap 200 lembaga kredit mikro, selama periode 1995-1996, menemukan bahwa variabel-variabel yang mempengaruhi kesuksesan lembaga adalah kondisi makro ekonomi yang kondusif, perkembangan lembaga yang terkontrol, mobilisasi dana dan pengendalian biaya (Ledgerwood, 1999). 


\section{Volume 3 No 1 (2020) 194-218 P-ISSN 2620-2956 \\ DOI 10.47467/elmal.v3i1.298}

Penelitian Kaluge, Susanto dan Dwiyoso (2008) terhadap dua model lembaga kredit mikro di Indonesia pada tahun 2001 menyimpulkan bahwa kesinambungan hidup lembaga kredit mikro sangat tergantung kepada besarnya biaya operasional dan penerimaan, dimana kedua faktor ini secara bersama-sama menentukan tingkat keuntungan. Secara rinci dikemukakan bahwa besarnya penerimaan/revenue, besarnya biaya operasional, tingkat angsuran, tingkat bunga pinjaman dan tingkat efisiensi merupakan varibel-variabel yang mempengaruhi kinerja dan kelangsungan hidup lembaga.

Yasin (2011) melakukan riset PUAP di Kabupaten Karawang. Hasilnya menyimpulkan bahwa Gapoktan penerima dana PUAP memiliki nilai R/C lebih tinggi sebesar 22,2\%, sehingga secara ekonomi lebih menguntungkan dari pada Gapoktan Non PUAP. Anita dan Susilawati (2011) melakukan riset dampak PUAP di Kabupaten Barito Kuala, Kalimantan Tengah. Hasilnya menyimpulkan bahwa dana BLM-PUAP sebagai tambahan modal bagi petani sangat berpengaruh terhadap pendapatan. Penelitian Rusbiana (2010) di Kabupaten 50 Kota, Sumbar, menunjukkan hasil yang kurang memuaskan. Menurutnya, adanya bantuan PUAP tidak mempengaruhi kegiatan usaha tani setempat.. Meski begitu, para petani merasakan manfaat lain, yakni ada kemudahan mendapat pinjaman dengan skema pengembalian yang jauh lebih ringan daripada pinjaman melalui rentenir.

Penelitian Dedi Junaedi (2012, 2013, dan 2014) menunjukkan bahwa LKMA PUAP di Jawa Tengah sebagian besar (87,5\%) berjalan dengan skema konvensional, dan hanya sekitar 12,5\% LKMA yang beroperasi dengan prinsip syariah (profit sharing).

Berbeda dengan penelitian sebelumnya, penelitian ini berusaha mengeksplorasi motif dan alasan Gapoktan memilih skema pembiayaan LKMA, membandingkan perbedaan motif pemilihan skema pembiayaan LKMA, serta menganalisis faktor-faktor yang mempengaruhi motif pemilihan skema syariah dan konvensional LKMA PUAP di Jawa Tengah.

\section{METODE PENELITIAN}

Metode penelitian ini mennggunakan kombinasi analisis kualitatif dan analisis kuantitatif (ekonometrika). Analisis deskriptif kualitatif dan kuantitatif dipakai untuk menjawab pertanyaan penelitian nomor satu. Analisis ini dipakai untuk menjelaskan motif pemilihan skema pembiayaan LKMA, dilengkapi dengan sajian data dalam bentuk tabel dan grafik. 


\section{Volume 3 No 1 (2020) 194-218 P-ISSN 2620-2956 \\ DOI 10.47467/elmal.v3i1.298}

Untuk menjawab pertanyaan penelitian nomor dua dan tiga digunakan analisa kuantitatif (ekonometrika). Analisis yang dipakai adalah analisis multiple regression dummy variabel dengan menggunakan panel data cross section, dilakukan untuk menelaah pengaruh skema pembiayaan syariah, umur lembaga gapoktan, jumlah anggota, jumlah penyertaan modal, jumlah pembiayaan, pendidikan manajerm serta keragaman kawasan terhadap kinerja keuangan LKMA yang terwakili oleh indikator likuiditas (Rasio Lancar), profitabilitas (NPM), aktivitas (ATO), dan solvabilitas (DER). Uji dan analisis statistik dilakukan menggunakan software SPSS 17.0.

Data yang digunakan adalah gabungan dari data primer dan data sekunder. Data primer dari lapangan adalah data terbaru laporan keuangan masing-masing sampel antara lain tentang jumlah anggota/nasabah, jumlah simpanan (pokok, wajib dan sukarela), penyertaan dana pihak ketiga, besarnya pembiayaan/total pendanaan/pinjaman yang disalurkan, pendapatan usaha simpan pinjam, jasa pinjaman, biaya operasional, laba usaha, bagi hasil atau SHU (sisa hasil usaha), kredit macet, dan jumlah aset. Motif dan alasan pemilihan skema pembiayaan, identitas, usia dan pendidikan manajer pengelola LKMA termasuk data yang dieksplorasi melalui survey angket dan FGD (Focus Group Discussion). Jumlah sampel 185 yang tersebar di lima kabupaten: Banjarnegara, Banyumas, Jepara, Kendal, dan Purbalingga.

Untuk analisa deskriptif dilakukan wawancara terstruktur dengan sampel purposif dan skema focus group discussion (FGD) dengan kuestioner tertentu. Kepada setiap sampel (35-40 per kabupaten) diajukan pilihan motif dan alasan pemilihan skema pembiayaan. Ada empat kelompok motif yang ditawarkan: motif agama (sesuai akidah, satu bentuk ibadah, ladang mencari pahala, dan sarana mencari berkah); motif ekonomi (mencari untung, nyaman, transaksi yang adil), motif praktis (mudah, praktis dan aman), motif relasi (pengaruh teman, keluarga, pembina, pimpinan). Masing-masing diukur dengan skala Likert 1-5 untuk katagori: sangat tidak sesuai, tidak sesuai, agak sesuai, sesuai, sangat sesuai.

Waktu penelitian berlangsung dua bulan, Oktober-November 2015. Provinsi Jawa Tengah dipilih menjadi lokasi penelitian karena dua pertimbangan. Pertama, lebih dari separuh LKMA PUAP ada di kawasan ini. Kedua, wilayah ini memiliki keragaman populasi LKMA PUAP syariah dan PUAP konvensional yang menarik. Yakni ada wilayah dominan LKMA PUAP syariah seperti Kabupaten Purbalingga. Ada wilayah dominan LKMA konvensional seperti Kabupaten Banjarnegara dan Banyumas. Ada yang wilayah di antara dua ekstrim, dimana LKMA syariah 


\section{Volume 3 No 1 (2020) 194-218 P-ISSN 2620-2956 \\ DOI 10.47467/elmal.v3i1.298}

dan konvensional relatif berimbang, seperti Kabupaten Jepara dan Kendal. Pemilihan wilayah sampel dilakukan secara purposif berdasarkan proporsi keragaman skema pembiayaan.

Data yang terkumpul selanjutnya dikelompokkan menjadi variabel terikat (dependen) dan variabel bebas (independen). Variabel terikat adalah motif pemilihan skema LKMA. Sedang variabel bebas ada sembilan, terdiri dari lima variabel numerik (usia lembaga, modal, biaya, pendanaa, utang); serta tiga variabel dummy (pendidikan manajer, skema pembiayaan dan kawasan). Jumlah modal sendiri bisa dirinci menjadi modal awal (dana BLM), modal sendiri (simpanan anggota), dan modal penyertaan (simpanan) pihak ketiga.

Dalam menganalisis pengaruh motif dalam pemilihan skema LKMA, peneliti mengajukan Model Ekonometrika (Motif) sebagai berikut:

MOTIF $_{1-4}=\beta_{0}+\beta_{1}$ Sharia $+\beta_{2}$ U-LKMA $+\beta_{3}$ Anggota $1+\beta_{4}$ Anggota $2+\beta_{5}$ Didik1 $+\beta_{6}$ Didik2 $+\beta_{7}$ Usia1 $+\beta_{8}$ Usia $2+\beta_{9} \mathrm{Kab} 1+\beta_{10} \mathrm{Kab} 2+\beta_{11} \mathrm{Kab} 3+\beta_{12 \mathrm{~K}} \mathrm{Kab} 4+\varepsilon$

Model ini dipakai untuk melihat faktor-faktor yang mempengaruhi macam-macam motif pemilihan skema pembiayan LKMA PUAP syariah dan konvensional. Variabel terikat MOTIF $1-4$ ada empat macam motif, yaitu: $\mathrm{M}_{1}$-Agama (motif karena pertimbangan agama), $\mathrm{M}_{2}$-Eko (motif karena pertimbangan ekonomi), $\mathrm{M}_{3}$-Prak (motif karena pertimbangan Praktis), dan $\mathrm{M}_{4}$-Rel (motif karena pertimbangan relasi).

\section{HASIL DAN PEMBAHASAN}

Selama periode 2008-2012, sudah ada 43.581 Gapoktan/desa PUAP di seluruh Indonesia. Di Jawa Tengah sendiri, ada setidaknya 4.665 Gapoktan penerima PUAP, dimana sekitar 2267 (48,6\%) unit sudah sudah memiliki LKMA.

Ternyata, sebagian besar (87,25\%) LKMA di Jateng, beroperasi dengan skema pembiayaan konvensional dan hanya 289 (12,75\%) menerapkan skema syariah (profit sharing). LKMA PUAP Syariah antara lain terdapat di Kabupaten Purbalingga (156 unit), Jepara (17 unit), Kendal (11 unit), Banjarnegara (5 unit), dan Banyumas (5 unit). Di luar itu masih terdapat 93 unit LKMA PUAP Syariah yang tersebar di sejumlah kabupaten lainnya di Jawa Tengah (BPTP Jateng, 2011).

Dari 185 sampel penelitian, ada 69 (37,3\%) LKMA beroperasi dengan skema syariah, dan $116(62,7 \%)$ beroperasi dengan skema konvensional. Seluruh responden di Kabupaten 


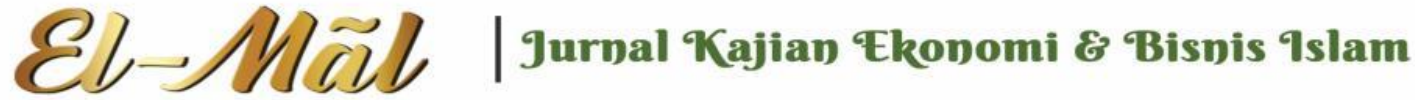

Volume 3 No 1 (2020) 194-218 P-ISSN 2620-2956

DOI 10.47467/elmal.v3i1.298

Purbalingga adalah LKMA yang beroperasi dengan skema pembiayaan syariah. Di Kabupaten Banyumas, ada 36 sampel LKMA yang mengisi kuesioner, tiga sampel atau 8,3\% dari populasi sampel beroperasi dengan skema syariah. Di kabupaten lain, porsi LKMA syariah berturut-turut adalah 19,4\% (Banjarnegara), 26\% (Kendal), dan 34,2\% (Jepara).

\section{Motif Pemilihan Skema Pembiayaan}

Tabel 1 Motif Pemilihan Skema LKMA PUAP

\begin{tabular}{|l|l|l|l|l|}
\hline Jumlah/Nilai & Motif Agama & $\begin{array}{l}\text { Motif } \\
\text { Ekonomi }\end{array}$ & Motif Praktis & Motif Relasi \\
\hline Syariah & $28(40,6 \%)$ & $17(24,6 \%)$ & $11(15,9 \%)$ & $13(18,8 \%)$ \\
\hline Konvensional & $15(12,9 \%)$ & $35(30,2 \%)$ & $41(35,3 \%)$ & $25(21,6 \%)$ \\
\hline
\end{tabular}

Sumber: Kuesioner, data diolah (Desember 2012)

Data hasil penelitian (Tabel 1) menunjukkan, 40,6\% responden memilih pertimbangan agama sebagai motif pemilihan skema syariah, Responden lainnya, 24,6\% memilih skema syariah karena motif ekonomi, 18,8\% memilih skema syariah karena pengaruh relasi, dan 15,9\% responden memilih skema syariah karena alasan praktis. Hasil FGD mengungkapkan bahwa PUAP syariah dalam persepsi responden dipilih karena skema ini lebih sesuai tuntutan akidah dan sebagai bentuk manifestasi ibadah. Selain itu, dengan memilih LKMA PUAP syariah responden berharap mendapat pahala, keberkahan dan kemaslahatan.

Tabel 2 Uji Anova Motif Pemilihan Skema LKMA PUAP

\begin{tabular}{|l|l|l|l|}
\hline & Gabungan & Syariah & Konvensional \\
\hline M-Agama & & & \\
\hline F & 48,777 & 4,594 & 1,257 \\
\hline Sig & $0,000^{a}$ & $0,000^{a}$ & $0,264^{a}$ \\
\hline M-Ekonomi & & & \\
\hline F & 3,713 & 1,851 & 3,567 \\
\hline Sig & $0,000^{a}$ & $0,066^{a}$ & $0,000^{a}$ \\
\hline M-Praktis & & & \\
\hline F & 1.765 & 1,691 & 1,731 \\
\hline Sig & $0,042^{a}$ & $0,099^{a}$ & $0,083^{a}$ \\
\hline
\end{tabular}


Volume 3 No 1 (2020) 194-218 P-ISSN 2620-2956

DOI 10.47467/elmal.v3i1.298

\begin{tabular}{|l|l|l|l|}
\hline M-Relasi & & 3.314 & \\
\hline F & 2,587 & 1,432 & 3,145 \\
\hline Sig & $0,001^{\mathrm{a}}$ & $0,184^{\mathrm{a}}$ & $0,001^{\mathrm{a}}$ \\
\hline
\end{tabular}

Sumber: Kuesioner, data diolah (Desember 2012)

Di lain pihak, para responden LKMA konvensional menunjukkan motif yang berbeda. Sekitar 35,3\% responden memilih skema konvensional karena alasan praktis dan 30,2\% responden memilih karena pertimbangan ekonomi. Motif pertimbangan relasi dipilih oleh $21,6 \%$ responden, dan hanya $12,9 \%$ responden memilih skema konvensional karena alasan pertimbangan agama.

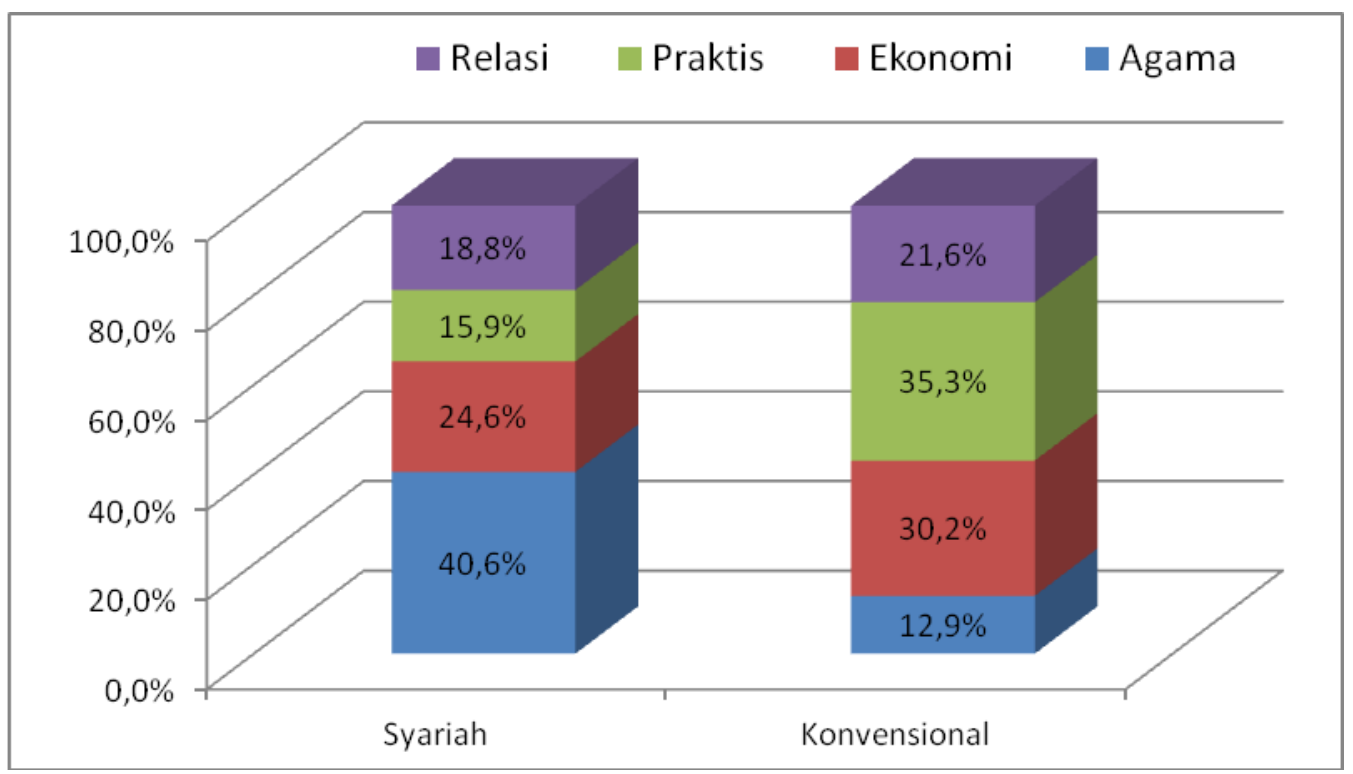

Sumber: Kuesioner, data diolah (Desember 2012)

\section{Grafik 1 Proporsi Motif Pemilihan Skema Pembiayaan LKMA}

Di mata responden, LKMA PUAP konvensional lebih praktis, aman, dan akrab dengan kebiasaan keseharian nasabah. Selain itu, mereka memiliki persepsi LKMA PUAP secara ekonomi lebih menjanjikan keuntungan, keadilan dan kenyamanan berusaha bagi para nasabah. Terlihat dari 65\% responden mengaku memilih PUAP konvensional karena pertimbangan praktis dan ekonomi. Faktor relasi menjadi pertimbangan penting bagi $21,6 \%$ responden dalam 


\section{Volume 3 No 1 (2020) 194-218 P-ISSN 2620-2956 \\ DOI 10.47467/elmal.v3i1.298}

memilih PUAP konvensional, sementara pertimbangan agama hanya diperhitungkan sebagai faktor motif oleh dipilih oleh $12,9 \%$ responden.

Dalam persepsi responden LKMA konvensional dinilai lebih praktis untuk dioperasikan karena mereka merasa tidak perlu tambahan pengetahuan dan keterampilan. Praktik simpan pinjam yang berbasis bunga sudah akrab dengan dunia keseharian mereka. Untuk pembukuan dan hitungan neraca lebih mudah dan sederhana. Persyaratan adanya akad dalam LKMA syariah memerlukan pemahaman dan keterampilan khusus, selain perlu seleksi yang lebih ketat. Sementara nasabah memerlukan proses yang sederhana dan cepat.

Jika dibuat skala Likert, responden LKMA syariah memberi skor relatif tinggi pada motif agama $(4,67)$ dan ekonomi $(4,62)$. Skor untuk motif pertimbangan praktis dan relasi dari para responden kelompok ini relatif lebih kecil atau sedikit di atas skala netral $(3,0)$, yakni: 3,84 (motif alasan praktis) dan 3,13 (motif pengaruh relasi).

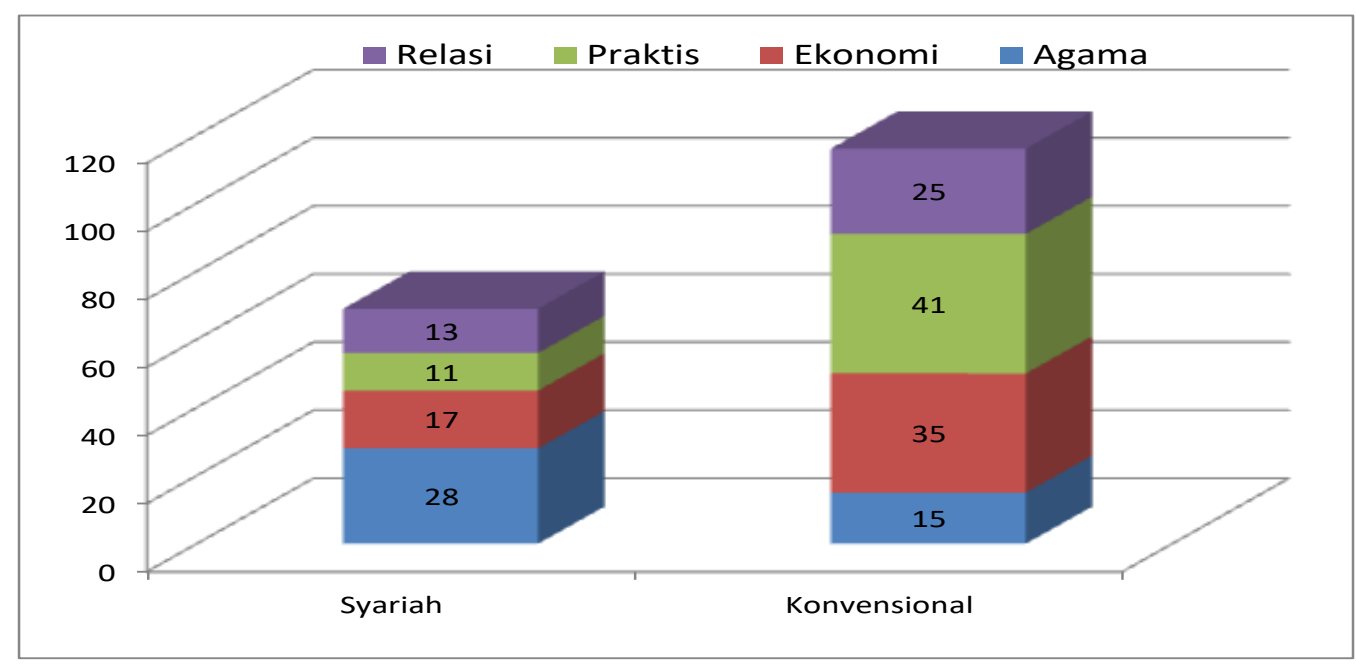

Sumber: Kuesioner, data diolah (Desember 2012)

\section{Grafik 2 Motif Pilihan Skema Pembiayaan LKMA PUAP}

Fakta riset telah menunjukkan bahwa populasi LKMA syariah masih kalah jauh dari LKMA konvensional. Apa yang bisa dijelaskan dari fenomena unik dan menarik ini? Keberadaan LKMA syariah dalam peta LKMA PUAP di Indonesia ini seperti barang bagus yang belum banyak dipilih orang karena sebagian besar orang tidak mengetahui barang itu betul-betul bagus dan sangat 


\section{Volume 3 No 1 (2020) 194-218 P-ISSN 2620-2956 \\ DOI 10.47467/elmal.v3i1.298}

diperlukan. Atau orang tahu barang itu bagus, tapi tidak tahu dimana dan bagaimana cara mendapatkannya.

Kurangnya sosialisasi dan terbatasnya akses terhadap pasar merupakan faktor utama yang bisa menjelaskan mengapa LKMA syariah belum menjadi pilihan utama. Dari diskusi di forum-forum FGD di lima kabupaten sampel, terungkap bahwa banyak manajer LKMA mengakui tidak paham tentang karakteristik dan kelebihan syariah dibanding konvensional. Yang mereka rasakan adalah untuk mengelola LKMA dengan skema syariah butuh persiapan dan pelatihan yang lebih lanjut. Di wilayah sekitar keberadaan PUAP tidak banyak ditemukan contoh praktik muamalah berskema syariah. Yang umumnya mereka kenal adalah praktik simpan pinjam ala koperasi dan pinjaman lewat rentenir.

Pada tahap awal penyaluran dana BLM PUAP diakui oleh para responden ada pelatihan singkat. Pelatihan itu dirasakan masih sangat singkat, dengan materi yang yang bersifat normatif dan umum, belum menyentuh muatan spesifik tentang kelebihan dan kekurangan masing-masing skema pembiayaan. Sebagian besar responden menyatakan tidak ada arahan dan bimbingan khusus tentang seluk-beluk LKMA syariah. Hanya sejumlah responden di Kabupaten Purbalingga yang menyatakan ada bimbingan dari PMT (Penyelia Mitra Tani) yang memiliki pengetahuan dan pengalaman mengelola BMT dan atau koperasi syariah.

Apakah benar ada perbedaan motif dalam pemilihan skema LKMA syariah dan LKMA konvensional? Untuk itu diperlukan uji F (Anova) dan uji t Motif. Hasil uji F SPSS 17.0 menunjukkan bahwa variabel umur lembaga (ULKMA), usia manajer (Usia1, Usia2), pendidikan manajer (Didik1, Educ2), Modal, Utang, Biaya, Kredit, dan keragaman kawasan (Kab1, Kab2, Kab3, dan Kab4) secara simultan berpengaruh nyata terhadap semua Motif pemilihan skema pembiayaan LKMA PUAP gabungan, tanpa membedakan PUAP syariah atau konvensional. .

Tabel 3 Uji F (Anova) Motif Pemilihan Skema LKMA PUAP

\begin{tabular}{|l|l|l|l|}
\hline & Gabungan & Syariah & Konvensional \\
\hline M-Agama & & & \\
\hline F & 48,777 & 4,594 & 1,257 \\
\hline Sig & $0,000^{\mathrm{a}}$ & $0,000^{\mathrm{a}}$ & $0,264^{\mathrm{a}}$ \\
\hline
\end{tabular}




\section{Cl, $1 / \mid$ TIV | Jurnal Kajian Ekonomi \& Bisnis Islam}

Volume 3 No 1 (2020) 194-218 P-ISSN 2620-2956

DOI 10.47467/elmal.v3i1.298

\begin{tabular}{|l|l|l|l|}
\hline M-Ekonomi & & & \\
\hline F & 3,713 & 1,851 & 3,567 \\
\hline Sig & $0,000^{\mathrm{a}}$ & $0,066^{\mathrm{a}}$ & $0,000^{\mathrm{a}}$ \\
\hline M-Praktis & & & \\
\hline F & 1.765 & 1,691 & 1,731 \\
\hline Sig & $0,042^{\mathrm{a}}$ & $0,099^{\mathrm{a}}$ & $0,083^{\mathrm{a}}$ \\
\hline M-Relasi & & 3.314 & \\
\hline F & 2,587 & 1,432 & 3,145 \\
\hline Sig & $0,001^{\mathrm{a}}$ & $0,184^{\mathrm{a}}$ & $0,001^{\mathrm{a}}$ \\
\hline
\end{tabular}

Sumber: Kuesioner, data diolah (Desember 2012)

Dari Tabel 3 diperoleh informasi bahwa nilai F dan Sig untuk semua Motif pada LKMA Gabungan cukup bermakna pada tingkat kepercayaan 95\% (toleransi $\alpha$ 5\%). Ini membuktikan bahwa variabel-variabel bebas tersebut secara simultan berpengaruh terhadap semua Motif pemilihan skema LKMA sampel keseluruhan. Dari nilai F, diketahui bahwa pengaruh variabel-variabel itu terhadap M-Agama paling kuat, disusul M-Ekonomi, M-Relasi dan M-Praktis. Dengan demikian, hipotesis $\mathrm{H}_{01}$ (Motif LKMA) ditolak. Artinya, variabel skema pembiayaan, usia LKMA, usia manajer, pendidikan manajer dan kawasan secara simultan berpengaruh terhadap motif pemilihan skema LKMA PUAP di wilayah penelitian.

Hasil yang berbeda terlihat, jika analisis uji F (Anova) dilakukan kepada kelompok LKMA PUAP yang homogen. Yakni uji F kepada kelompok LKMA syariah dan kelompok LKMA konvensional secara terpisah. Uji F terhadap motif LKMA syariah menunjukkan bahwa variabel-variabel bebas secara simultan berpengaruh nyata terhadap Motif Agama ( $\alpha$ 5\%). Jika toleransi error dinaikkan menjadi $\alpha 7 \%$, variabel bebas berpengaruh nyata terhadap Motif Ekonomi. Pengaruh variabel bebas secara simultan berpengaruh tidak nyata terhadap Motif Praktis dan Motif Relasi. Artinya. dalam pemilihan skema, rata-rata responden kurang mempertimbangkan alasan praktis dan relasi. Para responden memiliki persepsi bahwa skema syariah tidak atau belum praktis 


\section{Volume 3 No 1 (2020) 194-218 P-ISSN 2620-2956 \\ DOI 10.47467/elmal.v3i1.298}

diterapkan dalam lembaga keuangan mikro.Sebagian responden dalam FGD mengungkapkan mereka tidak memilih LKMA syariah karena tidak ada arahan dan berpandangan skema syariah sulit diterapkan. Mereka mengaku tidak punya pengetahuan dan keterampilan yang cukup untuk menjalankan skema syariah. Mayoritas responden syariah mengaku memilih skema PUAP syariah lebih karena pertimbangan agama.

Sementara itu, uji F terhadap kelompok LKMA konvensional, variabel-variabel bebas secara simultan berpengaruh nyata terhadap Motif Relasi dan Motif Ekonomi $\alpha$ 5\%). Motif Agama tidak nyata dipengaruhi oleh variabel-variabel bebas tersebut. Jika toleransi error dinaikkan ( $\alpha 10 \%$ ), variabel-variabel bebas berpengaruh terhadap Motif Praktis. Agak berbeda dengan yang terungkap secara lisan dalam FGD, bahwa LKMA konvensional dipilih lebih karena alasan praktis, ternyata dalam Uji F skala Likert pertimbangan praktis tidak terlalu kuat menjadi motif pemilihan LKMA konvensional. Banyak responden konvensional mengaku bahwa mereka menjalankan skema PUAP konvensional karena ada arahan dan pelatihan untuk itu, sementara mereka mengaku awam dengan konsep skema syariah.

Dari hasil analisis uji ANOVA dan FGD dapat dikatakan bahwa sebenarnya alasan praktis tidak terlalu kuat menjadi alasan para pengelola LKMA memilih skema syariah dan konvensional. Mereka akhirnya memilih skema konvensional karena adanya faktor pengaruh relasi dari pembina dan pendamping. Skema syariah tidak dipilih juga bukan karena syariah tidak menguntungkan dan tidak parktis, tetapi karena kurangnya pengetahuan dan masih minimnya pengaruh relasi. Sebagian besar PMT dan penyuluh mengungkapkan mereka awam dan tidak punya wawasan yang cukup untuk membimbing para manajer mengelola LKMA PUAP secara syariah. Tingginya animo terhadap skema syariah di Purbalingga, misalnya, lebih karena faktor PMT yang umumnya punya latar belakang pengalaman mengelola skema pembiayaan syariah dan dukunga relasi yang baik antara manajer, PMT dan pembina teknis di kabuipaten setempat. 


\section{Volume 3 No 1 (2020) 194-218 P-ISSN 2620-2956 \\ DOI 10.47467/elmal.v3i1.298}

Pertanyaan berikutnya, apakah secara parsial masing-masing variabel bebas berpengaruh terhadap Motif Skema LKMA? Untuk menjawabnya dilakukan uji $\mathrm{t}$ terhadap tiga kelompok Motif Skema LKMA. Hasilnya tampak pada Tabel 4 berikut.

Tabel 4 Hasil Uji t Motif Skema LKMA PUAP

\begin{tabular}{|l|r|r|r|r|r|r|r|r|}
\hline \\
Variabel
\end{tabular}

Sumber: Kuesioner, data diolah (Desember 2012)

Data Tabel 4 menunjukkan kondisi yang berbeda untuk setiap variabel bebas. Skema pembiayaan (Sharia) secara parsial berpengaruh nyata terhadap Motif Agama, Motif Ekonomi dan Motif Relasi. Sharia berpengaruh tidak nyata terhadap Motif Praktis.

Variabel Usia LKMA hanya berpengaruh nyata terhadap Motif Ekonomi. Jumlah anggota tidak berpengaruh nyata terhadap semua Motif. Usia manajer (Usia1, < 30 tahun) hanya berpengaruh terhadap Motif Praktis. Manajer Usia2 ( $>40$ ) berpengaruh terhadap Motif Ekonomi. Pendidikan manajer relatif tidak berpengaruh terhadap semua Motif. Variabel kawasan (Kab1) berpengaruh terhadap Motif Agama dan Motif Praktis. 


\section{Volume 3 No 1 (2020) 194-218 P-ISSN 2620-2956 \\ DOI 10.47467/elmal.v3i1.298}

Kab2 berpengaruh nyata terhadap Motif Agama. Kab3 berpengaruh terhadap Motif Relasi. Dan, Kab4 berpengaruh terhadap Motif Agama dan Motif Praktis.

\section{Motif Agama}

Pengaruh parsial dari masing-masing variabel bebas terhadap Motif pemilihan skema dapat dilihat pada tabel 4.9. Secara parsial Motif Agama dalam pemilihan LKMA dipengaruhi secara nyata oleh skema pembiayaan (Sharia), kawasan (Kab1), Utang, Kredit dan Biaya dengan level kepercayaan 95\%. Jika toleransi error 10\%, Motif Agama dalam pemilihan skema LKMA juga dipengaruhi oleh Anggota dan Kab4.

Variabel Sharia, Kab1, Anggota2, Utang dan Biaya berkorelasi positif dengan Motif Agama. Artinya, ada Motif Agama pada responden pemilih LKMA syariah lebih kuat dari responden pemilih LKMA konvensional. Motif Agama responden di Purbalingga lebih tinggi dari responden di Banjarnegara. Motif Agama dari LKMA yang beranggota banyak (> 200 orang) lebih tinggi dari LKMA kecil yang beranggota kurang dari 100 orang. Motif Agama cenderung bertambah kuat pada LKMA yang memiliki komponen biaya operaional dan utang yang lebih besar.

Korelasi negatif terjadi antara variabel Kredit dan Kab4 dengan Motif Agama. Artinya semakin besar suatu LKMA menyalurkan kredit pinjaman cenderung menurun adanya Motif Agama dalam pemilihin Skema LKMA. Motif Agama responden di Kabupaten Banyumas lebih rendah dari Motif Agama responden LKMA di Banjarnegara.

$\mathrm{R}^{2}$ 0,815 menunjukkan bahwa variabel-variabel tersebut dapat menjelaskan pengaruhnya terhadap Motif Agama sebesar 81,5, sisanya dijelaskan oleh variabel yang tidak diketahui.

Sejumlah responden penelitian dalam FGD mengungkapkan bahwa mereka memilih skema LKMA syariah karena ada kesesuaian dengan ideologi agama, ada nilainilai ibadah, berharap mendapat pahala; sebagian responden berharap mendapat berkah, dan menilai syariah lebih banyak memberi manfaat dan kemaslahatan.

\section{Motif Ekonomi}




\section{Volume 3 No 1 (2020) 194-218 P-ISSN 2620-2956 \\ DOI 10.47467/elmal.v3i1.298}

Dari hasil olah statistik uji t menggunakan SPSS 17.0 diperoleh hasil bahwa Motif Ekonomi dalam memilih LKMA dipengaruhi oleh variabel Sharia dan Usia LKMA. Variabel lain seperti usia manajer, pendidikan manajer, jumlah anngota, modal, biaya, utang dan kredit tidak nyata berpengaruh terhadap Motif Agama.

Variabel Sharia dan Usia LKMA berpengaruh positif terhadap Motif Ekonomi dalam memilih skema LKMA. Artinya Motif Ekonomi dalam pemilihan skema makin kuat jika usia LKMA bertambah dan LKMA terkait beroperasi secara syariah.

Usia LKMA juga berpengaruh nyata dan positif pada Motif Ekonomi. Artinya semakin lama usia LKMA semakin besar adanya pengaruh terhadap Motif Ekonomi dalam pemilihan skema LKMA PUAP. $\mathrm{R}^{2}$ senilai 0,276 artinya bahwa variabel-variabel tersebutt menjelaskan pengaruhnya terhadap Motif Ekonomi sebesar 27,6\%, sisanya dijelaskan oleh variabel lain yang tidak diteliti.

Dalam diskusi FGD, sebagian responden menyatakan mereka memilih skema konvensional karena percaya skema ini juga bisa lebih menguntungkan secara ekonomi; sebagian menilai syariah lebih menjanjikan kenyamanan dan keadilan yang lebih proporsional dengan tingkat keberhasilan usaha tani.

\section{Motif Praktis}

Hasil ujit t statistik terhadap variabel terikat Motif Praktis praktis diperoleh hasil berikut : hanya variabel kawasan (Kab1, Kab3, dan Kab4) yang berpengaruh nyata terhadap Motif Praktis pada level kepercayaan 95\%. Usia LKMA dan usia manajer (Usia1) berpengaruh nyata terhadap Motif Praktis dalam pemilihan skema LKMA PUAP pada level kepercayaan 90\%.

Variabel kawasan (Kab1, Kab3, Kab4) dan Usia LKMA berkorelasi positif dengan Motif Praktis. Artinya LKMA yang berusia lebih tua cenderung memiliki Motif Praktis yang lebih tinggi dari LKMA yang usianya lebih muda. Kemudian, LKMA yang berada di kawasan Purbalingga (Kab1), Jepara (Kab3) dan Banyumas (Kab4) memiliki Motif Praktis yang lebih kuat dari LKMA di kawasan Banjarnegara. 


\section{Volume 3 No 1 (2020) 194-218 P-ISSN 2620-2956 \\ DOI 10.47467/elmal.v3i1.298}

Sampai pada level kepercayaan 75\%, variabel Sharia tidak nyata berpengaruh terhadap Motif Praktis. Ini terjadi karena di mata sebagian pengelola LKMA, skema syariah dinilai kurang praktis. Mereka masih perlu waktu untuk meyakinkan para anggota bahwa skema syariah lebih baik dari skema konvensional. Pengaruh variabel Sharia baru berpengaruh nyata dengan tanda korelasi negatif pada level kepercayaan 70\% atau toleransi error 30\%. Ini memberi indikasi bahwa sebagian manajer LKMA memiliki persepsi bahwa LKMA syariah kurang praktis dibanding LKMA konvensional. $\mathrm{R}^{2}$ 0,147 artinya, variabel-variabel tersebut hanya dapat menjelaskan pengaruh sebesar $14.7 \%$, sisanya dijelaskan oleh variabel lain yang tidak diteliti.

Sebagian besar responden FGD berpandangan skema konvensional jauh lebih praktis dan lebih mudah dijalankan; sebagian responden juga berpandangan skema konvensional lebih aman dan lebih akrab dengan kebiasaan masyarakat setempat. Sebagian kecil responden berpendapat skema syariah agak rumit dan prosedurnya bertele-tele.

\section{Motif Relasi}

Hasil analisis uji t statistik menggunakan SPSS 17.0 menunjukkan bahwa variabel skema pembiayaan (Sharia), pendidikan manajer (Educ2), dan kawasan (Kab3. Kab4) berpengaruh nyata pada Motif Relasi dalam pemilihan skema pembiayaan pada level kepercayaan 95\%. Tiga variabel ini, skema pembiayaan, pendidikan manajer dan kawasan berkorelasi negatif dengan Motif Relasi. Ini memberi makna bahwa LKMA syariah memiliki Motif Relasi yang kurang kuat dibanding LKMA konvensional. Kemudian, LKMA yang dikelola oleh manajer berpendidikan sarjana memiliki Motif Relasi yang kurang kuat dibanding LKMA yang dikelola manajer tamatan SLTA. Jadi makin tinggi pendidikan manajer makin kurang adanya pengaruh Motif Relasi dalam pemilihan skema LKMA.

Selanjutnya, LKMA yang berlokasi di kawasan Jepara (Kab3) dan Banyumas (Kab4) rata-rata punya kecenderungan memiliki Motif Relasi yang lebih rendah dari LKMA di Banjarnegara. Di Jepara dan Banyumas Motif Relasi kurang menjadi 


\section{Volume 3 No 1 (2020) 194-218 P-ISSN 2620-2956 \\ DOI 10.47467/elmal.v3i1.298}

pertimbangan. Ini diduga terjadi karena di kawasan ini, komunikasi dan inter relasi antara PMT dan manajer, serta antar PMT dan pembina teknis di kabupaten terkait tidak terlalu baik. Di Jepara bahkan terungkap adanya sikap saling curiga antar PMT dan pembina teknis di Dinas Pertanian setempat. $\mathrm{R}^{2}$ dari model ekonometrika Motif Relasi adalah 0,188 . Artinya variabel-variabel ini hanya menjelaskan $18,8 \%$ pengaruh, sisanya dijelaskan variabel lain yang tidak diteliti.

Dalam FGD terungkap, sebagian responden memilih skema konvensional karena pengaruh pimpinan dan pembina LKMA. Sebagian responden berpandangan memilih skema syariah karena pengaruh teman dan keluarga. Hanya sebagian kecil responden mengungkapkan bahwa mereka memilih skema syariah atau konvensional karena pilihan sendiri.

\section{KESIMPULAN}

Berdasarkan pertanyaan penelitian, hasil analisis dan pembahasan atas data penelitian, maka dapat disimpulkan:

1. LKMA PUAP syariah dipilih karena pertimbangan agama $(40,6 \%)$, pertimbangan ekonomi ( 24,6\%), pertimbangan relasi $(18,8 \%)$ dan karena alasan praktis $(15,9 \%)$. Sementara LKMA PUAP konvensional dipilih alasan praktis (35,3\%), pertimbangan ekonomi $(30,2 \%)$, pertimbangan relasi $(21,6 \%)$ dan hanya $12,9 \%$ responden memilih karena pertimbangan agama.

2. Dalam persepsi responden, LKMA PUAP syariah dinilai lebih sesuai tuntutan akidah, bentuk manifestasi ibadah, ladang harapan mendapat pahala, keberkahan dan kemaslahatan. LKMA PUAP konvensional dinilai lebih praktis, aman, dan akrab dengan kebiasaan keseharian anggota.

3. Hasil uji statistik menunjukkan motif pemilihan skema pembiayaan LKMA dipengaruhi secara nyata oleh skema pembiayaan (Sharia), tingkat pendidikan (Didik), dan perbedaan kawasan (Kab). Motif pemilihan skema juga berbeda antara responden pemilih LKMA syariah dan responden pemilih LKMA konvensional.

\section{SARAN}




\section{Volume 3 No 1 (2020) 194-218 P-ISSN 2620-2956 \\ DOI 10.47467/elmal.v3i1.298}

Merujuk kepada hasil riset ini, peneliti dapat menyampaikan saran-saran sebagai berikut:

1. Skema LKMA PUAP syariah belum menjadi pilihan utama karena beberapa alasan: minimnya informasi yang memadai tentang cetak biru pengelolaan LKMA PUAP berbasis syariah, terbatasnya jumlah SDM yang kompeten, dan kurang intensifnya komunikasi antara manajer dan PMT maupun antar PMT dan pembina teknis di kabupaten dan provinsi, terutama dalam proses pembentukan dan operasionalisasi awal LKMA PUAP. Untuk itu, penulis mengajukan saran dan rekomendasi sebagai berikut:

a. Perlu segera disusun cetak biru dan panduan praktis pengelolaan LKMA PUAP berbasis syariah beserta langkah-langkah sosialisasi yang masif dan internalisasinya yang memadai.

b. Perlu adanya pendidikan dan pelatihan khusus untuk mempersiapkan SDM yang cakap, jujur, amanah dan profesional, serta pelatihan lanjutan untuk meningkatkan kapasitas dan kompetensi para pengelola LKMA dan Gapoktan PUAP.

c. Perlu adanya forum komunikasi dan interaksi yang lebih teratur, terstruktur dan terukur antara manajer LKMA dan pengelola Gapoktan, antara manajer dan PMT, serta antar PMT dan pembina teknis di kabupaten dan provinsi untuk menngatasi dan mengantisipasi setiap masalah yang muncul.

2. Untuk pendalaman, riset selanjutnya perlu dilakukan dengan mengambil sampel yang sebaran populasinya lebih seragam. Responden penelitian sebaiknya juga tidak beragam agar terjadi proses check and balance antar kelompok responden.

\section{DAFTAR PUSTAKA}

Alquran Al Karim.

Anita, Andi Suci; \& Salawati, Umi. (2011). Analisis pendapatan penerima bantuan langsung masyarakat pengembangan usaha agribisnis perdesaan (BLM-PUAP) di kabupaten Barito Kuala. Jurnal Agribisnis Perdesaan, Volume 01 Nomor 04 Desember 2011, pp 285-288.

Apriyantono, Anton. (2009). Memori akhir jabatan Menteri Pertanian RI 2004-2009. Jakarta: Biro Perencanaan Sekretariat Jenderal Kementan RI. 


\author{
Volume 3 No 1 (2020) 194-218 P-ISSN 2620-2956 \\ DOI 10.47467/elmal.v3i1.298
}

Ashar, Khusnul. (2011). Analisis terhadap kesinambungan lembaga pembiayaan pedesaan dalam mendukung usaha mikro, kecil dan menengah. Journal of Indonesian Applied Economics, Vol. 5 No. 1 Mei 2011, pp 57-67

Bahrein, S. (2010). Pendekatan desa membangun di Jawa barat: Strategi dan kebijakan pembangunan pedesaan. Analisis Kebijakan Pertanian Vol 8, No 2, Juni 2010, pp 133-149.

Bi, Zohra \& Pandey, S.L.D. (2011). Comparison of performance of microfinance institutions with commercial banks in India. Australian Journal of Business and Management Research Vol.1 No.6 [110-120] | September-2011.

Biro Perencanaan Departemen Pertanian. (2009). Evaluasi dan penilaian gapoktan PUAP. Jakarta: Biro Perencanaan Deptan.

BPTP Jawa Tengah. (2011). Laporan perkembangan LKMA PUAP di Jateng 2008-2011. Semarang: BPTP Jateng

BPS. (2008). Analisis dan penghitungan tingkat kemiskinan tahun 2008. BPS Indonesia. Jakarta.

BPS. (2012). Data strategis bps indonesia 2012: Beberapa indikator sosial-ekonomi. Jakarta: BPS.

Darwis, Valeriana dan Rusastra, I.W. (2011). Optimalisasi pemberdayaan masyarakat desa melalui sinergi puap dengan desa mandiri pangan. Jurnal Analisis Kebijaskan Pertanian, Volume 9 No 2 Juni 2011, pp 125-142. Bogor: Pusat Sosial Ekonomi dan Kebijakan Pertanian Badan Litbang Pertanian Kementerian Pertanian.

Gujarati, D.N. (1988). Basic Econometrics. New York: John Wiley \& Sons.

Hassan, H.H. (2007). All Arabs will prefer Islamic banking. Islamic Finance Resource. December 3, 2007. http://ifresource.com/2007/12/03/drhussein-hamid-hassan-all-arabs-will-prefer-islamicbanking/

Hashemi, Syed; Foose, Laura; and Badawi, Samer. (2005). Beyond good intentions measuring the social performance of microfinance institutions. Filipina: CGAP.

Hendriawan, Mulyadi. (2011). Pedoman umum PUAP. Jakarta: Pusat Pembiayaan Ditjen Prasarana dan Sarana Pertanian Kementerian Pertanian RI.

Hendiawan, Mulyadi. (2012). Laporan perkembangan pelaksanaan program PUAP 2008-2011. Jakarta: Pusat Pembiayaan Ditjen Prasarana dan Sarana Pertanian Kementerian Pertanian RI.

Huda, Nurul, Nasution, M.E., \& Wiliasih, R. (2008). Ekonomi makro Islam pendekatan teoritis. Jakarta: Kencana.

Huda, Nurul dan Muti, Ahmad. (2011). Keuangan Publik Islam: Pendekatan al-kharaj (imam Abu Yusuf). Bogor: Ghalia Indonesia. 


\author{
Volume 3 No 1 (2020) 194-218 P-ISSN 2620-2956 \\ DOI 10.47467/elmal.v3i1.298
}

Hussein, Kassim. (2010). Bank-level stability factors and consume confidence: A comparative study of Islamic and conventional bank' product mix. Journal of Financial Services Marketing, Vol.15,3, 259-270. www.palgrave-journals.com/fsm.

Junaedi, Dedi; Huda, Nurul, Wiliasih, Ranti, dan Sumarkidjo, Gatot I. (2012). Studi Komparasi Pengembangan Usaha Agribisnis Perdesaan di Jawa Tengah. 2012. Jurnal Agro Ekonomi, Vol 30, No 2, Oktober 2012. PSE-Balitbang Pertanian: Bogor.

Junaedi, Dedi. (2013). PUAP Syariah vs PUAP Konvensional: Sebuah Studi Komparasi. Kementerian Pertanian: Jakarta.

Kaluge, D., Susanto, M.H., dan Dwiyoso. (2008). Analisis fenomenologi bank mendirikan koperasi kredit. Journal of Indonesian Applied Economics, Vol. 2, 1, Mei 2008, pp 1-21

Kamira, Desi; Noer, Melinda; \& Tan, Firwan. (2011). Evaluasi pelaksanaan program pengembangan usaha agribisnis perdesaan (PUAP) di Kota Padang. Padang: Program Pasca Sarjana Universitas Andalas.

Khandker, S.R. and R.R. Farugee, 2001. The Impact of Farm Credit in Pakistan, World Bank Technical Paper No. 258, Washington, DC.

Kementan RI. (2010). Pedoman umum pengembangan usaha agribisnis perdesaan. Jakarta: Pusat Pembiayaan Ditjen PSP Kementan RI.

Kementan RI. (2011). Laporan pelaksanaan pengembangan usaha agribisnis perdesaan 2010. Jakarta: Pusat Pembiayaan Ditjen PSP Kementan RI.

Keown, A.J., Martin; Martin, J.D.; Petty, J.W.; and Scott, D.F. (2011). Manajemen Keuangan: Prinsip dan penerapan. (Marcus Prihmindo Widodo, Trans). Jakarta: Indeks.

Khan, Ajaz Ahmad.(2008). Islamic microfinance: theory, policy and practice. Birmingham: Islamic Relief Worldwide.

Khandker, Shahidur R. (2005). Microfinance and poverty: evidence using panel data from Bangladesh. World Bank Econ Rev (2005) 19(2): pp 263-286.

Khandker, Shahidur R. (2005). World bank institute's poverty reduction and economic management. www.oxfordjournals.org/content/19/2/263.

Khandker, S.R. and R.R. Farugee, 2001. The Impact of Farm Credit in Pakistan, World Bank Technical Paper No. 258, Washington, DC.

Lawai, Husain. (1994). Essentials of successful islamic banking. New Horizon, No31, September 1994, pp 4-8

Margaretha, Farah. (2011). Manajemen keuangan: Untuk manajer non-keuangan. Jakarta: Erlangga. 


\title{
Cl-N/Til | Jurnal Kajian Ekonomi \& Bisnis Islam
}

\author{
Volume 3 No 1 (2020) 194-218 P-ISSN 2620-2956 \\ DOI 10.47467/elmal.v3i1.298
}

Maududi Al, Abu A'la. (1980). Dasar dasar ekonomi dalam Islam dan berbagai sistem masa kini. Bandung: Al-Ma,arif.

Qardhawi Al, Yusuf. (1996). Konsep Islam dalam mengentaskan kemiskinan. Surabaya: Bina Islam.

Rahman, A A.R. (2010). Islamic microfinance: an ethical alternative to poverty alleviation. Humanomics, Vol. 26 No. 4, 2010, pp. 284-295.

Range, Mathias. (2004). Islamic microfinance. Research center of international technical and economical cooperation. Aschen: Faculty of Business Administration, Aachen University.

Rivai, R.S. et al. (2010). Laporan penelitan evaluasi dan penyusunan desa calon lokasi penerima puap. Jakarta: Pusat Analisis Sosial Ekonomi dan Kebijakan Pertanian Kementan RI.

Rivai, V.; Firmansyah, R.; Veithzal, A.P.; dan Rizqullah. (2010). Islamic financial management: Teori, konsep dan aplikasi, panduan praktis bagi lembaga keuangan dan bisnis, praktisi serta mahasiswa. Bogor: Ghalia Indonesia.

Rusbina, Endila. (2010). Analisis komparatif sistem usaha tanu padi sawah antara pra puap dan masa puap anggota gapoktan sinamar sungai rimbang, suliki, kabupaten lima puluh kota. Padang: Fakultas Pertanian Universitas Andalas

Sayogyo. (1982). Bunga rampai perekonomian desa. Jakarta: Yayasan Obor Indonesia.

Seibel, H.D., (2003). History Matters in Microfinance. International journal of Microfinance and Business Development, 10-12.

Seibel, H.D., dan Agung, D.W. (2005). Microfinance in Indonesia: institutional viability \& sustainability and their compatibility with outreach to the poor." Jakarta: GTZ Jerman.

Sevilla, C.G., Ochave, J.S., Punsalam, T.G., Regala, B.P., and Uriarte, G.G. (2006). Pengantar metode penelitian. (Alimuddin Tuwu dan Alam Sjah, Trans). Jakarta: UI-Press.

Sen, A. (1999). Employment, Technology, and Development. New Delhi: Oxford University Press.

Siregar, Hermanto. (2008). Impact of economic growth on the reduction of poor people. Bogor: IPB \& Brighten Institut.

Robert M. Solow. (1974). "The Economics of Resources or the Resources of Economics". The American Economic Review (American Economic Association) 64 (2): 1-14. 1974.

Subramanyam, K.R. and Wild, J.J. (2010). Analisis laporan keuangan. 10 th Ed. (Dewi Yanti, Trans). Jakarta: Salemba Empat.

Sudaryanto, Tahlim. (2010). PUAP untuk kesejahteraan rakyat. Jakarta: Pusat Studi Ekonomi dan Kebijakan Pertanian Kementan RI. 


\author{
Volume 3 No 1 (2020) 194-218 P-ISSN 2620-2956 \\ DOI 10.47467/elmal.v3i1.298
}

Sudaryanto, Tahlim; Sunarja, Rudy. (2009). Penentuan lokasi dan evaluasi kinerja serta dampak PUAP. Jakarta: PSEK Deptan.

Sumaryadi, I N. (2005). Perencanaan pembangunan daerah otonom dan pemberdayaan masyarakat. Jakarta: Penerbit Citra Utama.

Suradisastra, K., W.K. Sejati, Y. Supriatna, dan D. Hidayat. (2002). Institutional description of balinese subak. Jurnal Kajian Dan Pengembangan Pertanian, Vo. 21 No.1, 2002. Jakarta: Badan Kajian dan Pengembangan Pertanian, Departemen Pertanian..

Suradisastra, K. (2008). Strategi pemberdayaan kelembagaan petani. Forum Kajian Agronomi, Vol. 26 No.2, Desember 2008, pp 82-91. Pusat Analisis Sosial Ekonomi dan Kebijakan Pertanian. Bogor.

Suryahadi, A. Suryadarma, D, \& Sumarto, A. (2006). The impact of private growth sector in proverty reduction in indonesia: The effect of location and sectoral component of growth. Bogor: SMERU Working Paper.

Suswono. (2009). Rencana strategis pembangunan pertanian Indonesia 2009-2014. Jakarta: Biro Perencanaan Sekretariat Jenderal Kementerian Pertanian RI.

Syahyuti, (2007). Strategi dan tantangan dalam pengembangan gabungan kelompoktani (gapoktan) sebagai kelembagaan ekonomi di pedesaan. Bogor: Pusat Analisis Sosial Ekonomi dan Kebijakan Pertanian. Bogor.

Usman, Hardius; dan Nachrawi, N.D. (2002). Penggunaan teknik ekonometri: Pendekatan populer dan praktis, dilengkapi teknik analisis dan pengolahan data dengan menggunakan paket program SPSS. Jakarta: RajaGrafindo Persada.

World Bank. (2004). Microcredit international summit 2004. New York: World Bank.

Yasin, Akbar. (2011). Strategi keberlanjutan program pengembangan usaha agribisnis perdesaan (PUAP) (kasus kabupaten Karawang). Bogor: Sekolah Pascasarjana IPB.

Zain, M. Yunis. (2001). Technology policy and smes in Indonesia: reviewing the economic development strategy for the poor. Journal Economic Resources, Vol. II, No.5, /2001, pp: 131156. 